Надтока Віктор Олександрович

аспірант

Інститут педагогіки НАПН України, м. Київ, Україна

nadtoka.ol@ukr.net

\title{
ОСНОВНІ МОЖЛИВОСТІ ІНТЕРАКТИВНИХ КАРТ ПІД ЧАС ВИВЧЕННЯ ГІДРОЛОГІЧНИХ ПОНЯТЬ В ЕПОХУ ІНФОРМАЦІЙНИХ ТЕХНОЛОГІЙ У ФІЗИКО-ГЕОГРАФІЧНИХ КУРСАХ ОСНОВНОЇ ШКОЛИ
}

\begin{abstract}
Анотація. У даній статті охарактеризовано можливості інтерактивних карт у процесі формуванні гідрологічних понять у фізико-географічних курсах основної школи. Зроблено спробу знайти компромісне рішення у застосуванні інтерактивних карт в навчальному процесі, зважаючи на недостатню поширеність інтерактивних картографічних творів навчального характеру. Сформовано пропозицію, як можна підвищити ефективність формування гідрологічних понять, використовуючи інтерактивні карти вільного доступу, такі як GoogleMaps, GoogleEarth. Запропоновано модель створення учнівських інтерактивних карт відповідно запропонованої теми дослідження.
\end{abstract}

Ключові слова: інтерактивна карта; гідрологічні поняття; інформатизація.

\section{1. ВСТУП}

Постановка проблеми. Початок XXI століття характеризується значними темпами технологізації й інформатизації як глобальних соціальних процесів: світ усе більше переходить в еру інформаційного суспільства - інформатизація стає провідним видом діяльності. Інтелектуальні інформаційні системи відкривають глобальні перспективи для людей. Вони дають можливість говорити про світові інтегровані знання, що виходять за межі звичних обмежень. Сьогодення - це епоха комп'ютерних технологій. Сучасна молодь і учні синхронно вписуються в комп'ютерну й електронну культуру.

У середині XX століття відбулося перше подвоєння наукових знань, а вже в 70-ті роки обсяг наукової інформації подвоюється кожні 5 років, то в 80-ті вже подвоєння було кожні 2 роки, а в 90-ті подвоєння відбувалось кожен рік. Спочатку XXI століття обсяг наукових знань збільшилися більш ніж у 250 тис. разів [4, 5], що призводить одночасно до постійного збільшення обсягу навчальних понять і збільшення розриву між освітньою галуззю і наукою. На сьогодні інформація стає стратегічно важливим ресурсом й індикатором розвитку суспільства. У цьому аспекті вчитель має володіти сучасними інформаційними технологіями навчання і відповідними методиками, щоб координувати школяра в постійно прогресуючому інформаційному руслі.

Отже, нині викреслюється відносно нове завдання для вчителя географії допомогти учневі оперувати інформаційно-просторовими даними в інформаційному суспільстві, що вимагає оновлених підходів у навчанні географії - підручників, атласів та карт нового покоління.

Головним пріоритетом фізико-географічних курсів $\epsilon$ формування понять «Земля» $\mathrm{i}$ «Географічна оболонка», розширення бази знань про природу, забезпечення національної ідентифікації учнів, формування їхнього особистісного ставлення до перебігу регіональних (внутрішньодержавних) і глобальних (світових) географічних процесів [6]. Ці завдання можна реалізувати під час виконання досліджень і проектів, що регламентовані оновленою навчальною програмою для учнів 6-9 класів загальноосвітніх навчальних закладів з географії. 
У світлі вище перерахованих процесів поступово трансформуються й інформатизуються аспекти застосування гідрологічних знань у житті людини просторовості й мобільності. Відповідно, ці особливості все більше спрямовують на використання в процесі формування гідрологічних понять інтерактивних карт.

Аналіз останніх досліджень і публікацій. Дослідження різних особливостей інформатизації освітньої галузі в Україні характеризуються в роботах В. Бикова, М. Жалдака, В. Лапінського, А. Манако, Н. Морзе, С. Ракова, М. Солохи, О. Спіріна, О. Овчарук. Основні аспекти комп'ютерного навчання і використання інноваційних засобів навчання висвітлюються М. Грузманом, А. Гуржієм, А. Дишліком, В. Клочко, В. Корнєєвим, Ю. Рамським, І. Роберт, О. Співаковським. Важливі особливості роботи 3 інтерактивними картами розглядають у своїх працях такі дослідники як: О. Бардалін, Н. Бубир, Л. Даценко, Л. Миколенко, В. Остроух, В. Тейлор,

Мета статті. Охарактеризувати можливості інтерактивних карт у процесі формування гідрологічних понять у фізико-географічних курсах основної школи. Знайти компромісне рішення у застосуванні інтерактивних карт у навчальному процесі.

\section{2. РЕЗУЛЬТАТИ ДОСЛІДЖЕННЯ}

Модернізаційні й інформатизаційні тенденції в сучасній географічній освіті дають змогу задати напрям розвитку світогляду учня. На нашу думку, нині завдання фізичної географії в основній школі вже не обмежується вивченням певного обсягу понять і сприянням до розуміння учнем основних фізико-географічних закономірностей. Учень XXI-го століття має навчитися виражати свою позицію відповідно фізико-географічних процесів, користуючись інформаційно-просторовими даними, що постійно змінюються протягом усього життя. Отже, гідрологічні поняття, опрацьовані 3 допомогою динамічних можливостей інтерактивних карт, в учня мають сформувати свій погляд на похідні процеси.

В Україні майже $100 \%$ шкіл комп’ютеризовані, понад 90 \% учнів користується Інтернетом, не тільки в школі, а й в домашніх умовах. За даними дослідження Microsoft «ннновації в навчанні» можна зробити висновки, що не зважаючи на всі складнощі й недоліки, технічна підготовка вчителів у використанні ІКТ зростає й усе більше педагогів освоюють IT-навички. [7, 9, 10] Що надає можливість для повномасштабного впровадження інтерактивних карт у процес навчання географії і залучення учнів до роботи з ними, що надає можливість під час формування гідрологічних понять дати їм просторову характеристику в різних напрямках.

На сьогодні окремі розробники вже займаються проблемою створення і поширення інтерактивних карт в освітньому просторі, серед них можна відзначити: ДНВП «Картографія», ЗАТ «Інститут передових технологій», «Віртуальна школа Кирила i Мефодія», ДВНЦ «Природа», a Google, Яндекс та інші, що розробляють інтерактивні карти у вільному користуванні, для різних потреб людини.

За цільовим призначенням серед електронних картографічних видань можна виділити такі основні напрями:

- навчальні;

- пошуково-довідкові;

- топоатласи;

- космоатласи;

- комплексні;

- тематичні видання (туризм, карти й атласи автодоріг, екологія, транспорт тощо);

- спеціальні, виготовлені на замовлення для розв'язання відомчих прикладних задач (земельний кадастр, лісове господарство тощо) [2]. 
Як ми бачимо, інтерактивні карти вже зараз використовуються в більшості сфер життя людини, а в майбутньому це стане незамінним способом зображення мобільної просторової інформації. В основній школі вони створюють додаткову мотивацію й ефект одночасно різностороннього цікавого дослідження окремого гідрологічного поняття. Як зазначає Н. Бобир, використання інтерактивних карт у загальноосвітніх навчальних закладах сприяє підвищенню загальної успішності учнів на $22 \%$, успішності на репродуктивному, реконструктивному і творчому рівнях відповідно на13\%, 23 \% та $11 \%$ відповідно [3]. Підвищують ефективність формування гідрологічних понять в основній школі певні можливості інтерактивних карт, що виділяються такими дослідниками і розробниками, як О. Барладін, Н. Бубир, В. Остроух:

1) зміна інформаційної ємності карти;

2) проведення картометричних обчислень;

3) проведення аналітичних операцій;

4) ведення баз даних;

5) вихід в Інтернет;

6) друк зображення карти (Crl-PrtSc);

7) демонстраційні пошукові можливості карти (маніпулювання шарами, масштабування, малювання об' єктів, нанесення написів) $[1,3,11]$.

Зважаючи на вище зазначене, у вчителя географії з'являються неймовірні можливості комбінування, обробки та демонстрування різного виду інформації у просторовій площині. 3 більшістю основних гідрологічних понять учні ознайомлюються у шостому класі в початковому курсі фізичної географії, але найскладніші вивчаються у восьмому класі (водний баланс, водний режим та інші.). Ці поняття, з досвіду вчителівпрактиків, зважаючи на недостатню комплексність огляду, а відповідно цього і брак часу, формувалися і розвивалися в учнів дедуктивним шляхом (поняття $\rightarrow$ пояснення), але зараз, маючи можливість поєднувати й корегувати шари карти робити їх напівпрозорими, автоматично аналізувати і виражати обрану інформацію графічним способом, учень може сформувати дане поняття поступовим індуктивним шляхом (аналіз фактичної інформації $\rightarrow$ поняття $\rightarrow$ власна позиція), коли учень більш самостійно формує поняття.

Нині вчитель повинен сприймати інтерактивну карту не тільки як засіб навчання географії і спосіб відображення геопросторової інформації, а як плацдарм для формування і розвитку гідрологічних понять. 3 допомогою інтерфейсу і функціональних можливостей карти вчитель має спрямувати учня на розвиток здібностей самостійного навчання. Як зазначає В. Кулик, для естетичного оформлення інтерактивної карти слід раціонально використовувати Інтернет-ресурс[8].

Як ми бачимо із діаграми на рис. 1, що нині ще багато вчителів, зважаючи на можливості інтерактивних карт, не так часто використовують у своїй практиці роботу 3 інтерактивними картами. Утім, із 122 опитаних учителів більшість зазначає, що найбільша ефективність від використання такого засобу навчання саме на етапі вивчення нового матеріалу й на етапі закріплення вивченого матеріалу (рис. 2). У цьому питанні не можна не зважати на висновки міжнародних спеціалістів про низький якісний рівень комп'ютеризації освітніх закладів і комп'ютерної грамотності педагогів (61\% українських учителів відзначають, що недостатня кількість комп'ютерів залишається основною перешкодою для впровадження інформаційних технологій у школах; на 28 учнів припадав лише 1 комп'ютер...) [10], але також значною перепоною $є$ невелика кількість інтерактивних карт навчального характеру (або електронних навчальних картографічних творів 3 інтерактивними функціями), доступних широкому загалу в освітньому просторі. Тому, на нашу думку, доцільно було б використовувати електронні навчальні картографічні твори 3 інтерактивними функціями, що мають обмежені можливості, але знаходяться у вільному користуванні. 


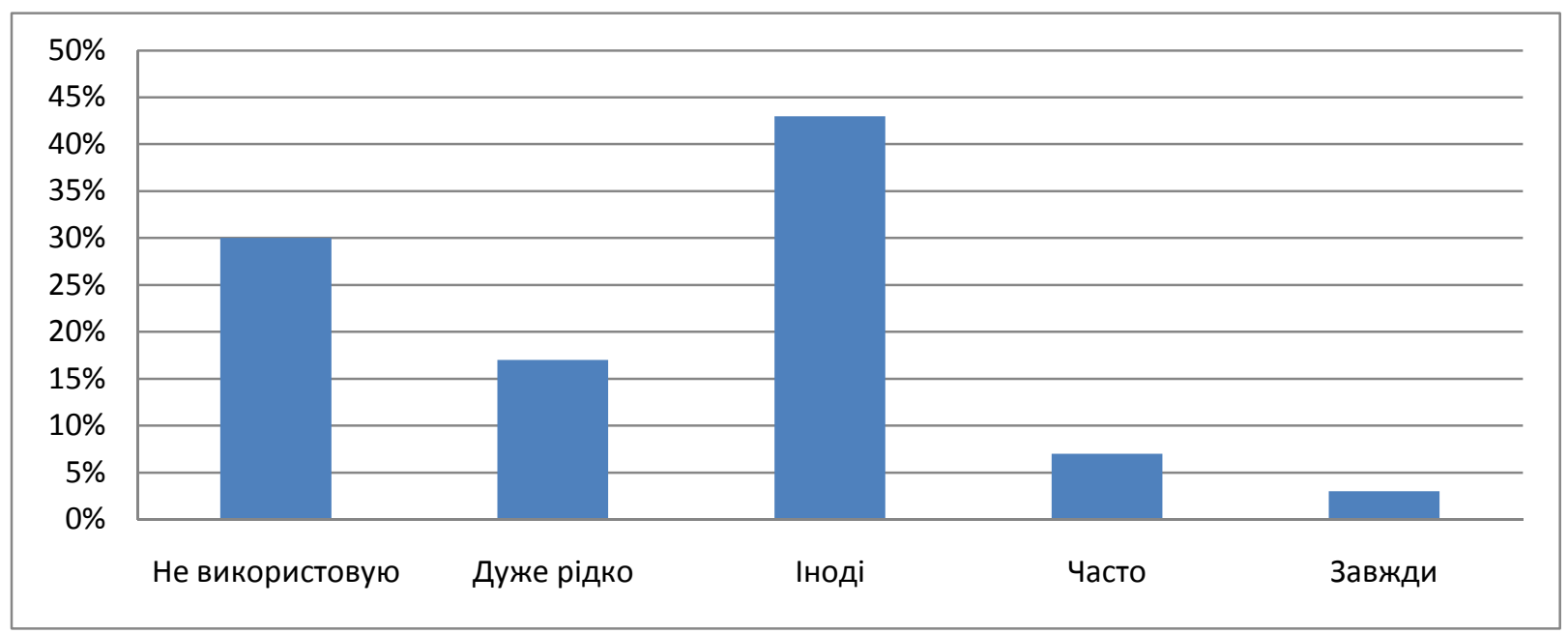

Рис. 1. Очінка інтенсивності використання інтерактивних карт у процесі навчання

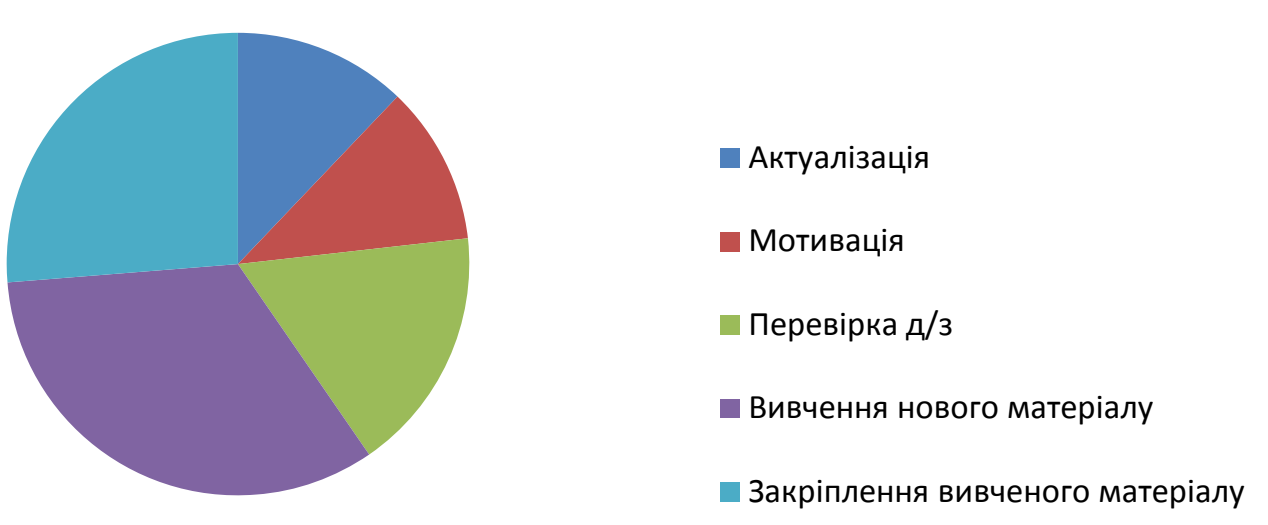

Рис. 2. Ефективність інтерактивних карт на різних етапах уроку

Значні здобутки у створенні інтерактивних карт вільного користування досягли деякі IT-компанії, такі як: Google, Yahoo, Yandex, META та інші. Міжнародна ITкорпораціяGoogle розробила сервіси GoogleEarth (рис. 3) i GoogleMaps (рис. 6).

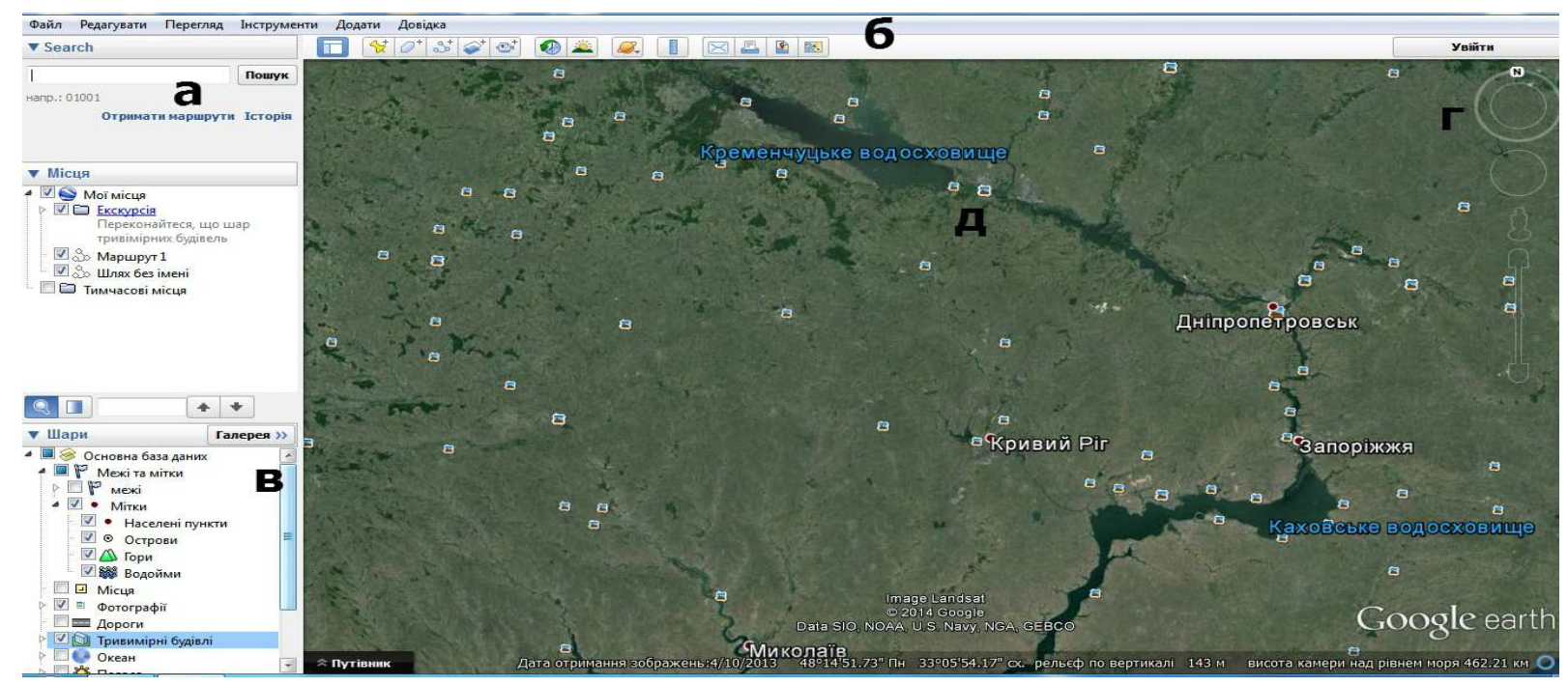

Puс. 3. Можливості GoogleEarth 
GoogleEarth має дуже простий і функціональний набір можливостей та інтерфейс (рис. 3, фрагмент б), що допомагає знайти об’єкт (рис. 3, фрагмент а) і в реальних умовах візуалізувати гідрологічне поняття для розуміння учнів 3 можливістю робити знімки (рис. 4,5 ). Інтерактивна карта укомплектована компасом і опцією масштабування (рис. 3 , фрагмент г), яка дозволяє користувачеві рухатися в просторі і змінювати масштаб споглядання карти (ці можливості будуть корисними у формуванні таких понять, як басейн річки, річкова система, вододіл та ін.).

Великий набір шарів (рис. 3, фрагмент в), яким можна оперувати, і медіа шар (рис. 3, фрагмент д), безпосередньо,із різних сервісів Google дозволяє оглянути обраний гідрологічний об’єкт з різних ракурсів. Додаткову зацікавленість і мотиваційний ефект надає можливість споглядати визначні об'єкти у 3d форматі.

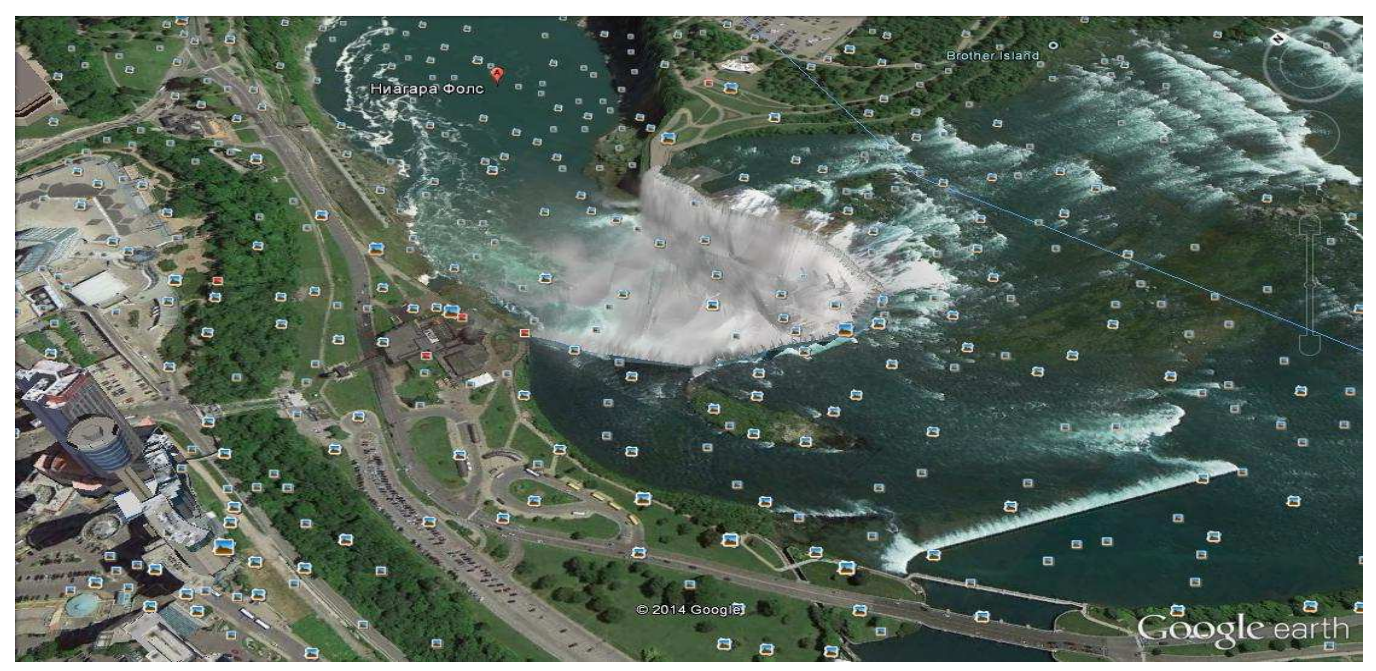

Рис. 4. Знімок із карти GoogleEarth (Ніагарський водоспад)

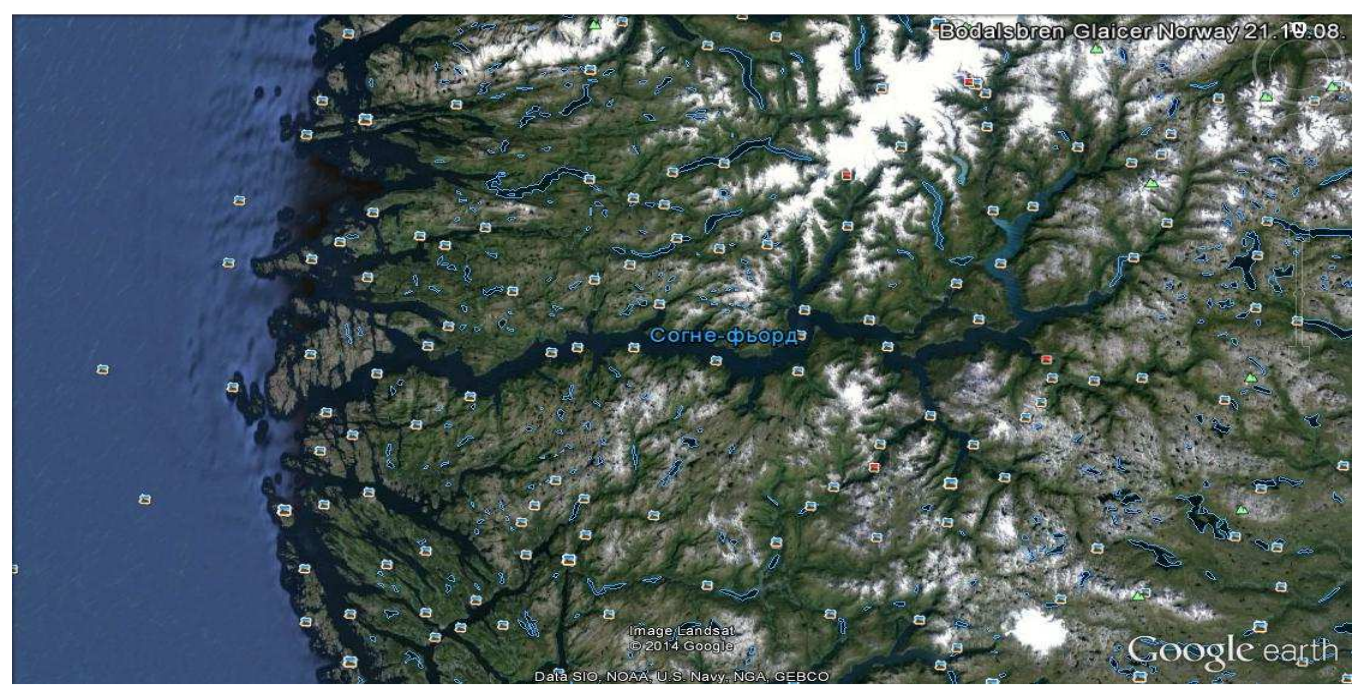

Рис. 5. Знімок із карти GoogleEarth (Фіорди)

Інший корисний сервіс, що допоможе вчителю й учням у виконаннях проектів, досліджень i, навіть, практичних робіт, — це GoogleMaps. Для відображення просторової складової дослідження чи проекту учень може використати досить простий інтерфейс (рис. 6, фрагмент а), що складається 3 лінійки (дає можливість визначити довжину поперечного розрізу будь-якої річки для розрахунку водного стоку), пунсону (який можна збагатити медіа додатками), лінії (що дозволяє малювати прості малюнки). 
GoogleMaps дозволяє користувачеві створювати безліч шарів карти (рис. 6, фрагменти в, б), компонувати їх i ділитися своїми інтерактивними картами i результатами дослідження в мережі Інтернет на своєму сайті. Також $є$ можливість панорамного $3 \mathrm{~d}$ перегляду різних визначних об’ єктів: річок, водоспадів, що створює ефект присутності.

Для того щоб почати створювати інтерактивні карти, варто зареєструвати свій профіль на сервісі GoogleMaps, зайти за адресою mapsengine.google.com/map й обрати опцію «створити карту».

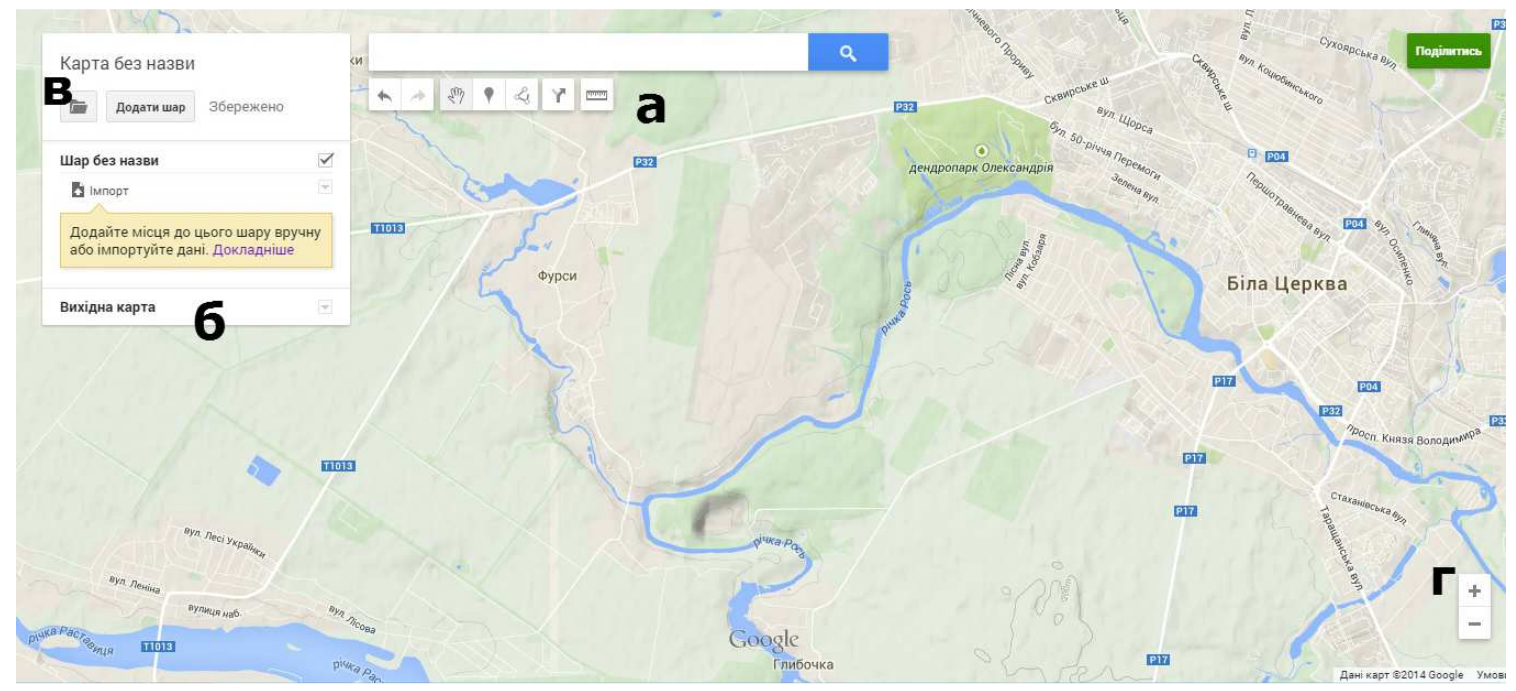

Рис. 6. Можливості GoogleMaрs у дослідницькій роботі учнів

Проводячи дослідження або виконуючи проект із гідрологічної тематики, учень може одночасно багатоаспектно у просторовому відношенні зобразити результати своєї роботи Наприклад, виконуючи практичну роботу 3 позначення гідрологічної номенклатури учні можуть не тільки позначити річки, озера, моря, а й доповнити їх фото, відеоматеріалами і цікавою інформацією, що дозволить не тільки розширити обсяг окремих загальних понять, а й допоможе учневі створити своє враження про окремий гідрологічний об'єкт.

\section{3. ВИСНОВКИ ТА ПЕРСПЕКТИВИ ПОДАЛЬШИХ ДОСЛІДЖЕНЬ}

Розвиток інформаційних технологій проходить дуже швидкими темпами як у світі, так і в Україні. Освітній простір поступово реагує на постійно зростаючі запити суспільства. В останні роки активізувалися розробки новітніх інформаційних засобів навчання, таких як інтерактивні карти й електронні навчальні картографічні твори 3 інтерактивними функціями, але поки що ними не забезпечені всі курси і їх не вистачає в широкому доступі. У цих умовах, на нашу думку, підвищило б ефективність формування гідрологічних понять використання інтерактивних карт вільного доступу, таких як, наприклад, GoogleMaps, GoogleEarth.

Використання навчальних електронних атласів і карт з інтерактивними функціями значно розширює оглядовість і методичні можливості викладачів, а також підвищує продуктивність роботи учнів. Розширення переліку карт 3 функцією пошарового виведення тематичного змісту уможливлює детальне порівняння різних природничих явищ і об'єктів з можливістю деталізації. Важливим елементом цих творів $є$ реалізація опції малювання і створення власних векторних шарів [2]. 
Отже, нині використовуючи інтерактивні карти під час формування гідрологічних понять, учитель географії має допомогти учневі сформувати свій особистий погляд на процеси, що відбуваються в гідросфері, а в подальшому і свою світоглядну позицію.

\title{
СПИСОК ВИКОРИСТАНИХ ДЖЕРЕЛ
}

1. Барладін О. В. Використання електронних атласів "Адміністративно-територіальний поділ України" та"Україна туристична" в освітніх цілях / О .В. Барладін, І. В. Бусол, Л. І. Миколенко [Текст] // Проблеми безперервної географічної освіти і картографії : зб. наук. пр. $-\mathrm{X}$.: ХНУ ім. В. Н. Каразіна, 2012. - Вип. 15. - С. 14-17

2. Барладін О. В. Створення електронних картографічних творів / О. Барладін, Л. Миколенко // Сучас. досягнення геодез. науки та вир-ва. - 2011. - Вип. 2. - С. 155-160.

3. Бубир Н. О. Електронні навчальні картографічні твори з інтерактивними функціями для потреб системи безперервної географічної освіти [Текст] / Н. О. Бубир // Вісник геодезії та картографії. 2011. 一 № 3. - C. 11-18.

4. Вірковський А. П. Синергетичний підхід до освітніх технологій навчання й виховання [Текст] / А. П. Вірковський, Т. С. Гужанова // Вісн. Житомир. держ. пед. ун-ту. — 2003. — № 12. — С. 186-189.

5. Дорогунцов С. Освітня сфера в інформаційному суспільстві [Текст] / С. Дорогунцов, В. Куценко // Вісник Національної академії наук України. - 2002. - № 11. - С. 3-10 [Електронний ресурс]. Режим доступу : http://nbuv.gov.ua/j-pdf/vnanu_2002_11_1.pdf.

6. Концепція географічної освіти в основній школі: проект / Інститут педагогіки НАПН України / за заг. ред. О. М. Топузов, О. Ф. Надтока, Л. П. Вішнікіна, А. С. Доброскок та ін. - К. : Педагогічна думка, 2014. - $30 \mathrm{c.}$

7. Кремінь В. Г. Інформатизація освіти - провідний напрям підвищення результативності навчального процесу [Текст] // Комп'ютер у школі та сім'ї. — 2011. — №1. - С. 3-6.

8. Кулик В. Б. Використання Інтернет-ресурсу для естетичного оформлення картографічних творів [Текст] // Проблеми безперервної географічної освіти і картографії : зб. наук. пр. - К.: Ін-т передових технолог, 2009. - Вип. № 10. - С. 112-116.

9. Мадзігон В. М. Інформатизація освіти в Україні: стан, проблеми, перспективи [Текст] // Комп'ютер у школі та сім'ї. - 2011. - №8. - С. 3-8.

10. Недостатня комп'ютеризація шкіл залишається перешкодою для розвитку інноваційної освіти [Електронний ресурс]. — Режим доступу : https://www.microsoft.com/ukraine/news/issues/2011/05/pilsurvey.mspx.

11. Остроух В. І. Нові навчальні електронні посібники з курсу "Фізична географія України" як форма реалізації іноваційних технологій в освітньому процесі літературний покажчик [Текст] // Вісник геодезії та картографії. - 2013. - №1. - С. 33-36.

Матеріал надійшов до редакиії 26.11.2014 p.

\section{ОСНОВНЫЕ ВОЗМОЖНОСТИ ИНТЕРАКТИВНЫХ КАРТ ПРИ ИЗУЧЕНИИ ГИДРОЛОГИЧЕСКИХ ПОНЯТИЙ В ЭПОХУ ИНФОРМАЦИОННЫХ ТЕХНОЛОГИЙ В ФИЗИКО-ГЕОГРАФИЧЕСКИХ КУРСАХ ОСНОВНОЙ ШКОЛЫ}

\author{
Надтока Виктор Александрович \\ аспирант \\ Институт педагогики НАПН Украины, г. Киев, Украина \\ e-mail: nadtoka.ol@ukr.net
}

\begin{abstract}
Аннотация. В данной статье охарактеризованы возможности интерактивных карт в процессе формировании гидрологических понятий в физико-географических курсах основной школы. Сделана попытка найти компромиссное решение в применении интерактивных карт в учебном процессе, учитывая недостаточную распространенность интерактивных картографических произведений учебного характера. Сформировано предложение как можно повысить эффективность формирования гидрологических понятий, используя интерактивные карты свободного доступа, такие как GoogleMaps, GoogleEarth. Предложена модель создания ученических интерактивных карт в соответствии с предложенной темой исследования.
\end{abstract}


Ключевые слова: интерактивная карта; гидрологические понятия; информатизация.

\title{
KEY FEATURES OF INTERACTIVE MAPS WHILE STUDYING HYDROLOGICAL CONCEPTS IN THE ERA OF INFORMATION TECHNOLOGY IN THE PRIMARY SCHOOL PHYSIOGRAPHIC COURSE
}

\author{
Viktor O. Nadtoka \\ graduate student \\ Institute of Pedagogy of NAPS of Ukraine, Kyiv, Ukraine \\ nadtoka.ol@ukr.net
}

\begin{abstract}
This paper describes the possibilities of interactive map in the formation of hydrological concepts while studying physiographic course in primary school. It was made an attempt to find a compromise in the use of interactive maps in the learning process, taking into account the lack of prevalence of interactive cartographic products for educational purpose. It is proposed the ways for increasing the efficiency of formation of hydrological concepts using free access interactive maps, such as Google Maps, Google Earth, as well as the model of students' interactive maps creation.
\end{abstract}

Keywords: interactive map; hydrologic concepts; informatization.

\section{REFERENCES (TRANSLATED AND TRANSLITERATED)}

1. Barladin O. V. The use of electronic atlases "Subdivisions Ukraine" and "Tourist Ukraine" for educational purposes/ O.V. Barladin, I. V. Busol, L.I. Mykolenko [Text] // Problemy bezperervnoyi heohrafichnoyi osvity i kartohrafiyi: zb. nauk. pr. - Kh. : KhNUim. V. N. Karazina, 2012. — Vyp. 15. - S. 14-17 (in Ukrainian).

2. Barladin O. V. Create electronic cartographic products / O. Barladin, L. Mykolenko // Suchas. Dosyahnennya heodez. naukyta vyr-va. - 2011. - Vyp. 2. - S. 155-160 (in Ukrainian).

3. Bubyr N. O. Electronic educational cartographic works wit hinter active functions forth needs of the continuous geographic education [Text] / N. O. Bubyr // Visnyk heodeziyi ta kartohrafiyi. — 2011. - \# 3. - S. 11-18 (in Ukrainian).

4. Virkovs'kyy A. P. Synergetic approach to education technology training and education [Text] / A. P. Virkovs'kyy, T. S. Huzhanova // Visn. Zhytomyr. derzh. ped. un-tu. — 2003. — \# 12. — S. 186-189 (in Ukrainian).

5. Dorohuntsov S. Education in the information society [Text] [online] / S. Dorohuntsov, V. Kutsenko // Visnyk Natsional'noyi akademiyi nauk Ukrayiny . - 2002. — \# 11. - S. 3--10. - Available from : http://nbuv.gov.ua/j-pdf/vnanu_2002_11_1.pdf(in Ukrainian).

6. The concept of geographic education in the elementary school: the project/ Instytut pedahohiky NAPN Ukrayiny / Zazah. red. O. M. Topuzov, O. F. Nadtoka, L. P. Vishnikina, A. S. Dobroskoktain. - K.: Pedahohichna dumka, 2014. - 30 s. (in Ukrainian).

7. Kremin' V. H. Informatization of Education - key ways to increase efficiency of the educational process [Text] // Komp'yuter u shkoli ta sim'yi. — 2011. — \#1. - S. 3-6 (in Ukrainian).

8. Kulyk V. B. Use online resource for esthetic design of cartographic products [Text] // Problemy bezperervnoyi heohrafichnoyi osvity i kartohrafiyi : Zb. nauk. pr. - K. : In-t peredovykh tekhnoloh., 2009. - Vyp. \# 10. - S. 112-116 (in Ukrainian).

9. Madzihon V. M. Informatization of Educationin Ukraine: State, Problems and Prospects [Text] // Komp'yuter u shkoli ta sim'yi. — 2011. — \#8. - S. 3-8 (in Ukrainian).

10. Lack of computerization of schools is an obstacle to the development of innovative education [online]. — Available from : https://www.microsoft.com/ukraine/news/issues/2011/05/pilsurvey.mspx (in Ukrainian).

11. Ostroukh V. I. New training manuals, electronic course "Physical Geography of Ukraine" as a formofimplementationofinnovativetechnologiesineducationliteratureindex [Text] // Visnyk heodeziyi ta kartohrafiyi. — 2013. — \#1. - S. 33-36 (in Ukrainian). 